\title{
The global-scale impacts of climate change on water resources and flooding under new climate and socio-economic scenarios
}

\author{
Nigel W. Arnell • Ben Lloyd-Hughes
}

Received: 17 December 2012 / Accepted: 21 September 2013 / Published online: 24 November 2013

(C) The Author(s) 2013. This article is published with open access at Springerlink.com

\begin{abstract}
This paper presents a preliminary assessment of the relative effects of rate of climate change (four Representative Concentration Pathways - RCPs), assumed future population (five Shared Socio-economic Pathways - SSPs), and pattern of climate change (19 CMIP5 climate models) on regional and global exposure to water resources stress and river flooding. Uncertainty in projected future impacts of climate change on exposure to water stress and river flooding is dominated by uncertainty in the projected spatial and seasonal pattern of change in climate. There is little clear difference in impact between RCP2.6, RCP4.5 and RCP6.0 in 2050, and between RCP4.5 and RCP6.0 in 2080. Impacts under RCP8.5 are greater than under the other RCPs in 2050 and 2080. For a given RCP, there is a difference in the absolute numbers of people exposed to increased water resources stress or increased river flood frequency between the five SSPs. With the "middle-of-theroad' SSP2, climate change by 2050 would increase exposure to water resources stress for between approximately 920 and 3,400 million people under the highest RCP, and increase exposure to river flood risk for between 100 and 580 million people. Under RCP2.6, exposure to increased water scarcity would be reduced in 2050 by $22-24 \%$, compared to impacts under the RCP8.5, and exposure to increased flood frequency would be reduced by around $16 \%$. The implications of climate change for actual future losses and adaptation depend not only on the numbers of people exposed to changes in risk, but also on the qualitative characteristics of future worlds as described in the different SSPs. The difference in 'actual' impact between SSPs will therefore be greater than the differences in numbers of people exposed to impact.
\end{abstract}

\section{Introduction}

It is widely recognised that anthropogenic emissions of greenhouse gases are likely to lead to changes in climate over the 21 st century and beyond, and the impacts of these changes have the potential to be substantial. However, the projected impacts of climate change depend on

Electronic supplementary material The online version of this article (doi:10.1007/s10584-013-0948-4) contains supplementary material, which is available to authorized users.

N. W. Arnell $(\bowtie) \cdot$ B. Lloyd-Hughes

Walker Institute for Climate System Research, University of Reading, Reading, UK

e-mail: n.w.arnell@reading.ac.uk 
future emissions of greenhouse gases, how these emissions translate into geographical and seasonal changes in climate, the state of the society and economy to which these changes apply, and the models used to estimate impacts from specified changes in climate.

Future emissions and the future state of society are inherently unknowable, and are typically represented by suites of plausible scenarios. Many studies have used the IPCC's SRES scenarios (IPCC 2000) to characterise future emissions and socio-economic characteristics. The emissions trajectories in these scenarios were determined by the assumed socio-economic conditions; the A2 socio-economic storyline is matched with an A2 emissions profile, and so on. However, such an approach does not readily allow an assessment of the relative importance of emissions trajectories (or the rate of climate change) versus socio-economic futures on the potential consequences of climate change. A new assessment methodology therefore adopts a 'matrix' approach, assessing impacts under different combinations of rate of change and socioeconomic futures (Moss et al. 2010; van Vuuren et al. 2012). Under this approach, the rate of climate change is characterised by four Representative Concentration Pathways (RCPs: Moss et al. 2010; van Vuuren et al. 2011a), defining different amounts of radiative forcing on the atmosphere. Socio-economic futures are characterised by five Shared Socio-economic Pathways (SSPs: O'Neill et al. 2012). In principle, each SSP can be combined with each RCP to produce $5 \times 4$ combinations of projected impact, although some combinations of SSP and RCP may be be unlikely to arise in practice.

The translation of RCPs into changes in climate and impacts is uncertain in a different way. The uncertainty arises because of a lack of understanding of how processes operate and challenges in the representation of processes within climate and impact models. Uncertainty in projections of geographical and seasonal changes in climate is typically accounted for by using an ensemble of climate models. Under the CMIP (Coupled Model Intercomparison Project) phase 5 exercise (CMIP5: Taylor et al. 2012), climate modelling groups have applied a number of climate models to produce an ensemble of estimates of change in climate for each RCP. In contrast, impacts assessments have so far typically used only one impacts model.

Assessments of climate change as simulated with CMIP5 models forced by RCPs are beginning to appear in the literature (e.g. Scheff and Frierson 2012; Monerie et al. 2012; Diffenbaugh and Giorgi 2012; Knutti and Sedláĉek 2013), but so far only one socioeconomic impact assessment has been published (Hanasaki et al. 2013). This paper presents a preliminary assessment of the global and regional scale impacts of climate change on exposure to water scarcity and changes in the frequency of river flooding, using the new matrix methodology. It estimates impacts in 2050 and 2080, under different combinations of rate of climate forcing (RCPs) and socio-economic futures (SSPs), using a suite of 19 CMIP5 climate models to characterise uncertainty in the geographical and seasonal pattern of change in climate.

\section{Scenarios and indicators}

\subsection{Introduction}

The methodology has the following stages:

(i) define climate change scenarios from each of 19 climate models forced with each RCP, representing changes in 2040-2069 ('2050s') and 2070-2099 ('2080s') relative to 1961-1990;

(ii) apply these changes to the CRU TS3.10 (Harris et al. 2013) $0.5 \times 0.5^{\circ}$ gridded 1961-1990 climate time series using the delta method; 
(iii) run a global-scale hydrological model with the baseline climate and the future climates;

(iv) combine hydrological impacts under each RCP and climate model with each of the five SSPs to estimate impacts on exposure to water resources stress and changes in river flood frequency. In each case, the impacts of climate change in a given year are expressed relative to the situation in that year in the absence of climate change.

Impacts are calculated at the $0.5 \times 0.5^{\circ}$ resolution, and then aggregated to the regional scale.

\subsection{Climate scenarios}

The four RCPs represent different trajectories of anthropogenic radiative forcing on the atmosphere. RCP2.6, RCP4.5, RCP6.0 and RCP8.5 respectively represent forcings of 2.6, $4.5,6.0$ and $8.5 \mathrm{~W} / \mathrm{m}^{2}$ by $2100\left(\mathrm{RCP} 2.6\right.$ has a peak forcing of $3 \mathrm{~W} / \mathrm{m}^{2}$ before declining to $2.6 \mathrm{~W} / \mathrm{m}^{2}$ ). The RCPs differ not only in their radiative forcings but also in the assumed pathways for changes in aerosols.

Scenarios have been constructed from 19 CMIP5 climate models (Supplementary Table 1) which have been run for all four RCPs. Figure 1 shows the change in global mean temperature under each RCP for each of the 19 models, together with the ensemble mean temperature change for each RCP. For a given RCP, the range in change in global mean temperature across the 19 models is between $1.1^{\circ} \mathrm{C}$ and $1.3{ }^{\circ} \mathrm{C}$ in 2050 . The broad spatial and seasonal patterns of change in climate are similar, but are some substantial differences in some areas between models (Allan et al. 2013). Knutti and Sedlácek (2013) note that both the spatial patterns of change and the spread across CMIP5 models are similar to those produced by the previous generation CMIP3 models. The assessment here assumes that all of the 19 climate models are equally plausible, but the models are in fact not all independent. The 19 models represent variants of 10 different models, and Knutti et al. (2013) classify models into 'families' based on their genealogy and component parts.

The climate scenarios were developed by extracting time series for monthly temperature, precipitation, vapour pressure and cloud cover for the model periods 2040-2069 and 2070-2099, and comparing monthly means with means calculated over the model years 1961-1990. Only one

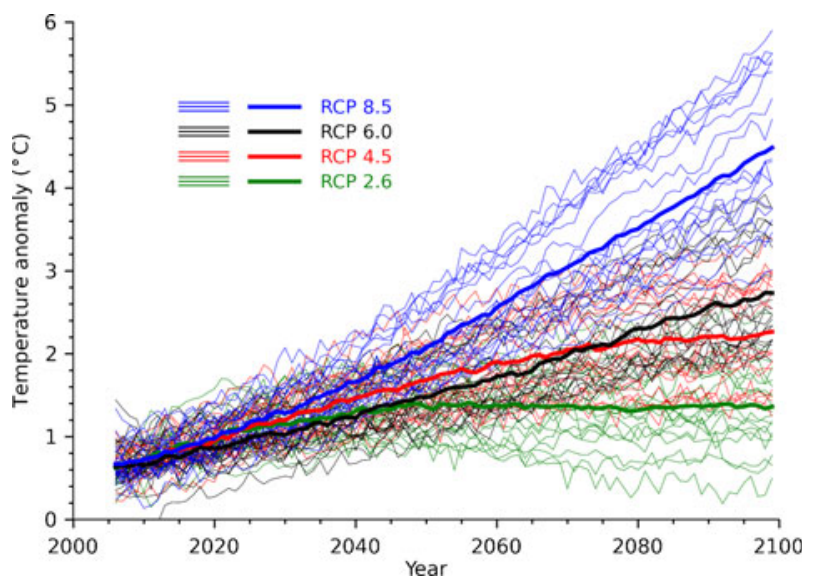

Fig. 1 Change in global mean temperature, relative to 1961-1990, under the four RCPs. The plot shows the individual model projections, plus the ensemble mean for each RCP 
realisation was used for each climate model. The climate data are interpolated from the native climate model resolution (ranging from $1.1 \times 1.1^{\circ}$ to $2.8 \times 2.8^{\circ}$ : Supplementary Table 1 ) to $0.5 \times 0.5^{\circ}$ using spherical interpolation. The scenarios represent only changes in 30 -year mean monthly climate. There is no change in the relative variability in climate from year to year.

Future 30-year time series were constructed by applying the model scenarios to the CRU TS3.1 1961-1990 time series. Precipitation and vapour pressure changes were applied multiplicatively, whilst temperature and cloud cover changes were applied additively. The number of rain days in each month is assumed unchanged, so precipitation intensity on each day in a month changes by the same rate. There is evidence (Allan and Soden 2008) that climate change would lead to disproportionate increases in precipitation during high precipitation events, but this is not incorporated here.

\subsection{The global hydrological model}

River flows are simulated across the global domain at a spatial resolution of $0.5 \times 0.5^{\circ}$ using the global hydrological model MacPDM.09 (Gosling and Arnell 2011; Arnell and Gosling 2013a). MacPDM.09 calculates the water balance on a daily time step from precipitation and potential evaporation, and river flows are generated by quick flow from saturated parts of the catchment and slow flow from drainage from soil and groundwater. Daily input data are disaggregated stochastically from the monthly climate inputs, and the model is run 20 times to produce 2030 year sequences for each grid cell. River flows are routed within each grid cell to simulate daily flow regimes typical of small to medium-sized catchments (between 1,200 and 2,500 km², depending on latitude), but flows are not routed from one grid cell to another. Average annual runoff is aggregated to the watershed scale for the estimation of water resources stress (Gosling and Arnell 2013). There are approximately 1,300 watersheds worldwide (excluding Greenland and Antarctica but including islands: Supplementary Figure 1), with the 10 to $90 \%$ area range between 8,000 and $250,000 \mathrm{~km}^{2}$. Flood frequency curves are calculated for each grid cell by fitting a GEV distribution to the simulated $20 \times 30$ annual maximum daily flows (see Arnell and Gosling 2013a for more details and a validation).

MacPDM.09 simulates river flow regimes well and is broadly consistent with other global hydrological models (Haddeland et al. 2011), although — in common with other models - tends to overestimate runoff in dry areas because evaporation of infiltrated runoff (for example transmission loss along the river channel) is not included. Simulated changes in hydrological behaviour are sensitive to hydrological model form, particularly representation of evaporation (Hagemann et al. 2013). MacPDM.09 produces changes in runoff which are consistent with those of other global hydrological models using the Penman-Monteith formulation.

\subsection{Socio-economic scenarios}

The Shared Socio-economic Pathways (SSPs) represent five different development pathways, each with a different narrative description and a quantitative characterisation. The five SSPs are distinguished on the basis of the socio-economic challenges to adaptation and mitigation (O'Neill et al. 2012), as summarised in Table 1. The quantitative analysis here uses just the SSP population projections, which make different assumptions about population fertility, mortality and migration, together with education, in different groups of countries (https:// secure.iiasa.ac.at/web-apps/ene/SspDb). Any interpretation of the quantitative results, however, needs to be made in the context of the narrative descriptions of the five development pathways.

The SSP population projections are currently only available at the national level, and so preliminary projections at the $0.5 \times 0.5^{\circ}$ resolution were made by rescaling $0.5 \times 0.5^{\circ} \mathrm{SRES}$ 
A1b population projections (from van Vuuren et al. 2007). These preliminary projections all assume the same rate of urbanisation (as in SRES A1b), and do not therefore reflect the different assumptions about urbanisation in the 5 SSPs. This would not substantially affect estimated exposure to water resources stress, because this is calculated at the watershed rather than individual grid cell level (see Section 2.5), but may have a larger effect on estimated flood-prone populations.

The population living in river floodplains was estimated by combining the high-spatial resolution CIESIN GRUMP gridded population data set (CIESIN 2004) with flood-prone areas defined in the UN PREVIEW Global Risk Data Platform (preview.grid.unep.ch), and calculating the proportion of the year 2000 population in each $0.5 \times 0.5^{\circ}$ grid cell living in flood-prone areas. It is assumed that the proportion of grid cell population living in floodprone areas does not change over time, implying that there is no preferential movement towards (or away from) flood-prone areas.

Table 2 shows the total global population and the population living in major river floodplains in 2000, 2050 and 2080, under the five SSPs. Around $10 \%$ of the world's population in 2000 lives in flood-prone areas, with $60 \%$ of these in south and east Asia. $90 \%$ of the year 2000 population lived in just 300 of the 1,300 watersheds, and around 260 watersheds had less than 10,000 people. Total population decreases after 2050 in both SSP1 and SSP5, but continues to increase in the other three SSPs. There are some differences in the regional distribution of future population between the five SSPs, but these are small compared to the differences in absolute regional populations between the SSPs.

\subsection{Indicators of impact}

A number of studies have assessed the impacts of climate change on exposure to water resources stress, using several different metrics and aggregating over several different spatial scales (e.g. Oki and Kanae 2006; Alcamo et al. 2007; Hanasaki et al. 2008, 2013; Rockstrom et al. 2009; Hayashi et al. 2010; Gerten et al. 2011; Wada et al. 2011). Some global water resources assessments use indices based on the relationship between withdrawals and available supplies, and others also incorporate the effects of withdrawals and other human interventions on the availability of water downstream. Here, exposure to water resources stress is based on the simple indicator of average annual runoff per capita: a watershed is deemed to be exposed to water resources stress if watershed average annual runoff is less than $1,000 \mathrm{~m}^{3} /$ capita/year. This is an arbitrary threshold, but one used in previous studies (Alcamo et al. 2007; Hayashi et al. 2010; Arnell 2004; Arnell et al. 2011; Gosling and Arnell 2013). The simple indicator is used primarily to allow comparisons with previous assessments. Projections of future water withdrawals are highly uncertain (compare the projections made by Alcamo et al. (2007) and Shen et al. (2008) under SRES scenarios, for example).

Table 2 shows the global total number of people living in water-stressed watersheds in 2000 , 2050 and 2080 under the five SSPs, assuming the 1961-1990 climate. The proportion of people

Table 1 Shared socio-economic pathways (O’Neill et al. 2012)

\begin{tabular}{lll}
\hline SSP1 & Sustainability & Low challenges to mitigation or adaptation \\
SSP2 & Middle of the road & Intermediate challenges \\
SSP3 & Fragmentation & High challenges to both mitigation and adaptation \\
SSP4 & Inequality & Low challenges to mitigation, but high adaptation challenges \\
SSP5 & Conventional development & Low challenges to adaptation, but high challenges to mitigation \\
\hline
\end{tabular}


Table 2 Total global population, water-stressed population and river flood-prone population. The waterstressed population assumes 1961-1990 climate

\begin{tabular}{|c|c|c|c|c|c|}
\hline & SSP1 & SSP2 & SSP3 & SSP4 & SSP5 \\
\hline \multicolumn{6}{|l|}{2000} \\
\hline Total population (m) & & & 6092 & & \\
\hline Water-stressed population (m) & & & 1559 & & \\
\hline Flood-prone population (m) & & & 634 & & \\
\hline \multicolumn{6}{|l|}{2050} \\
\hline Total population (m) & 8411 & 9245 & 10233 & 9368 & 8508 \\
\hline Water-stressed population (m) & 3286 & 4079 & 4774 & 4236 & 3350 \\
\hline Flood-prone population (m) & 847 & 931 & 1041 & 907 & 846 \\
\hline \multicolumn{6}{|l|}{2080} \\
\hline Total population (m) & 7959 & 9782 & 12477 & 1073 & 8244 \\
\hline Water-stressed population (m) & 3147 & 4480 & 6767 & 5556 & 3291 \\
\hline Flood-prone population (m) & 763 & 936 & 1213 & 931 & 768 \\
\hline
\end{tabular}

living in water-stressed watersheds increases from around $27 \%$ in 2000 to between $41 \%$ and $49 \%$ in 2050 due to population change alone. $69 \%$ of the water-stressed people in 2000 live in south and east Asia, with most of the rest in north Africa, central Asia and western Europe.

A change in exposure to water stress due to climate change is assumed to occur where average annual runoff in water-stressed watersheds changes significantly or where runoff either falls below the $1,000 \mathrm{~m}^{3} /$ capita/year threshold or rises above it (see also Arnell 2004; Arnell et al. 2011). A significant change in average annual runoff is greater than the standard deviation of 30-year average annual runoff, which is typically between $5 \%$ and $10 \%$ of the 1961-1990 average annual runoff (Arnell and Gosling 2013a). Where runoff decreases significantly, the water-stressed watershed population is exposed to an increase in stress, and where runoff increases the watershed population sees an apparent reduction in stress. It is not appropriate to calculate the net effect over a region partly because the adverse effects of a reduction in water in water-stressed watersheds are likely to be more severe than the beneficial effects of an increase, and partly because deficits in one major watershed are not easily offset by increases in others (Arnell et al. 2011).

The impacts of climate change on river flood risk are much less well studied than impacts on water resources (Arnell and Gosling 2013b). The indicator of impact used here is the number of flood-prone people living in areas where the frequency of the baseline (19611990) 20-year flood either doubles (occurs more frequently than one in 10 years) or halves (occurs more rarely than one in 40 years). Again, these thresholds are arbitrary (although the results are not very sensitive to changes in threshold definition), and because the indicator does not incorporate any assumptions about levels of protection against flooding, does not necessarily translate very closely into average annual numbers of people actually flooded.

\section{Impacts at the global and regional scales}

Figure 2 and Table 3 show the global scale impacts of climate change in 2050 on the populations exposed to changes in water stress and frequency of river flooding, by RCP and SSP, across the 19 climate models. The ensemble mean assumes all 19 models are equally plausible. 
There is clearly considerable variability in impact between climate models. With SSP2 and RCP8.5, for example, between 920 and 3,500 million people are exposed to increased water stress, and between 100 and 580 million people are exposed to increased river flood frequency. Similar numbers of water-stressed people live in watersheds with increased runoff, but the numbers of flood-prone people experiencing a reduction in flood frequency are smaller than those seeing an increase. The range in estimates reflects the different spatial patterns of change in climate with the different models. This is illustrated in Fig. 3, which shows the regional variation in impact between the climate models, under RCP8.5 and SSP2 in 2050. Most of the variation in the global total is accounted for by differences between models in impacts in south and east Asia, where the bulk of the populations exposed to water scarcity and flooding live(see Supplementary Figures 2 and 3: note that with this indicator and at the scale of analysis here, no watersheds in Australasia are deemed to be in the waterstressed category in 2050). The models which project large increases in exposure to water resources stress are generally those which project the smallest increase in exposure to river flooding (Supplementary Figure 4). There are strong similarities in impact on water resource stress between climate models within the same model families as identified by Knutti et al. (2013) (Supplementary Figure 5), but greater within-family variation for flood impacts.

For a given RCP, there is a difference in impact between SSPs. This largely reflects different overall population totals but differences in the regional distribution of population between SSPs account for some of the differences. SSP2 and SSP4 have similar global total populations, but the numbers of people exposed to increased water scarcity are greater in SSP4
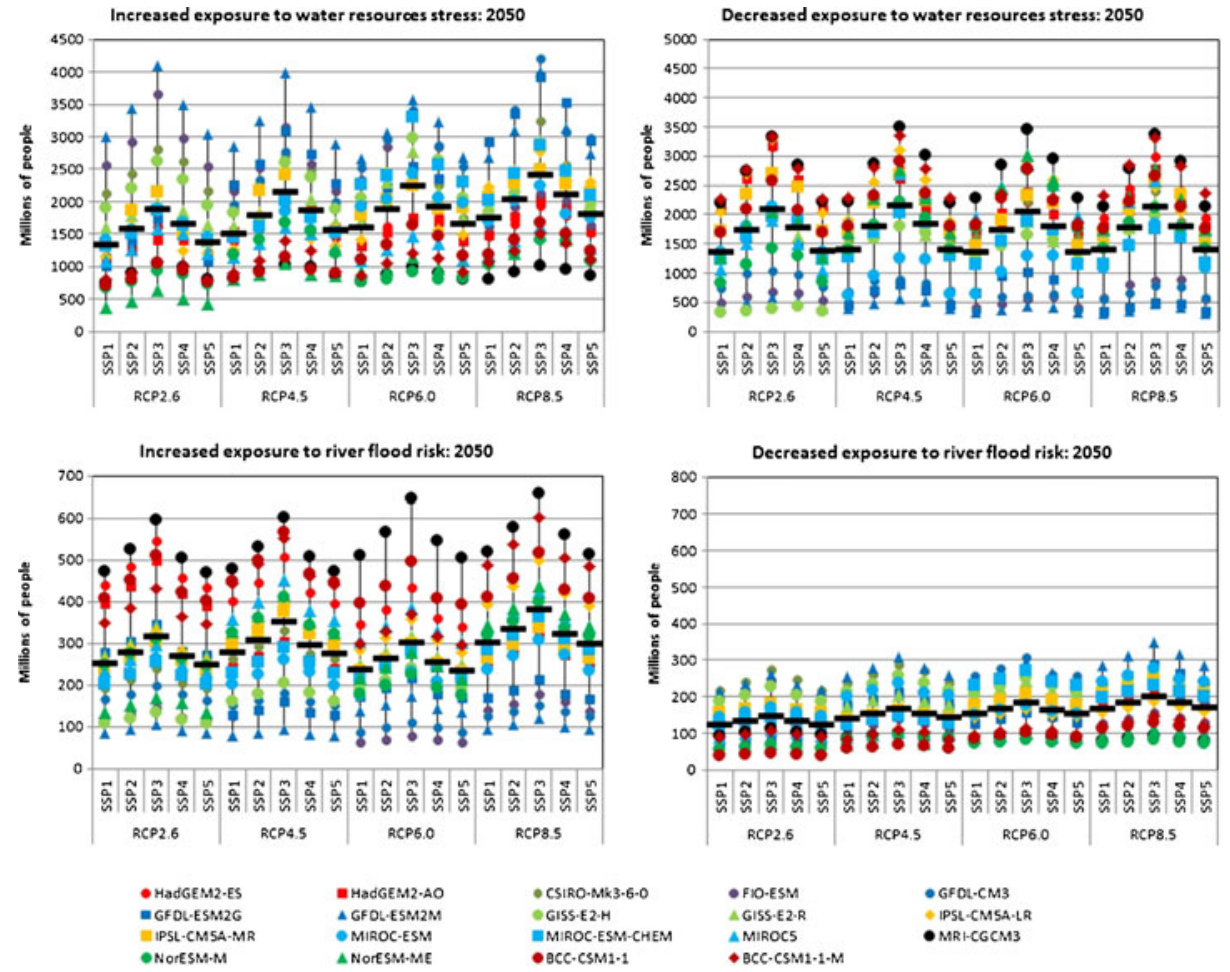

Fig. 2 Changes in exposure to water resources stress and river flood risk; global scale 2050. The ensemble mean is shown by the black line 
Table 3 Exposure to climate change impact by RCP and SSP: 2050

\begin{tabular}{|c|c|c|c|c|c|}
\hline & SSP1 & SSP2 & SSP3 & SSP4 & SSP5 \\
\hline \multicolumn{6}{|c|}{ a) Numbers of people (millions) exposed to increased water resources stress } \\
\hline RCP8.5 & $\begin{array}{l}1754 \\
(802-2947)\end{array}$ & $\begin{array}{l}2027 \\
(919-3416)\end{array}$ & $\begin{array}{l}2421 \\
(1006-4201)\end{array}$ & $\begin{array}{l}2105 \\
(950-3519)\end{array}$ & $\begin{array}{l}1810 \\
(854-2981)\end{array}$ \\
\hline RCP6 & $\begin{array}{l}1602 \\
(759-2668)\end{array}$ & $\begin{array}{l}1878 \\
(807-3054)\end{array}$ & $\begin{array}{l}2244 \\
(924-3564)\end{array}$ & $\begin{array}{l}1920 \\
(809-3227)\end{array}$ & $\begin{array}{l}1649 \\
(803-2682)\end{array}$ \\
\hline $\mathrm{RCP} 4.5$ & $\begin{array}{l}1514 \\
(810-2845)\end{array}$ & $\begin{array}{l}1794 \\
(881-3239)\end{array}$ & $\begin{array}{l}2157 \\
(1037-3975)\end{array}$ & $\begin{array}{l}1867 \\
(884-3444)\end{array}$ & $\begin{array}{l}1566 \\
(854-2879)\end{array}$ \\
\hline $\mathrm{RCP} 2.6$ & $\begin{array}{l}1330 \\
(379-2997)\end{array}$ & $\begin{array}{l}1575 \\
(473-3434)\end{array}$ & $\begin{array}{l}1887 \\
(626-4088)\end{array}$ & $\begin{array}{l}1656 \\
(508-3481)\end{array}$ & $\begin{array}{l}1375 \\
(418-3033)\end{array}$ \\
\hline
\end{tabular}

b) Numbers of people (millions) exposed to decreased water resources stress

$\begin{array}{llllll}\text { RCP8.5 } & 1409 & 1783 & 2132 & 1808 & 1407 \\ & (303-2330) & (352-2850) & (472-3379) & (414-2917) & (307-2358) \\ \text { RCP6 } & 1352 & 1726 & 2059 & 1791 & 1354 \\ & (320-2288) & (362-2859) & (431-3461) & (404-2964) & (333-2281) \\ \text { RCP4.5 } & 1408 & 1801 & 2163 & 1837 & 1407 \\ & (388-2279) & (473-2877) & (554-3492) & (508-3011) & (401-2281) \\ \text { RCP2.6 } & 1364 & 1745 & 2092 & 1779 & 1369 \\ & (329-2254) & (352-2775) & (390-3338) & (432-2841) & (341-2255)\end{array}$

c) Numbers of people (millions) exposed to increased river flood frequency

$\begin{array}{llllll}\text { RCP8.5 } & 302 & 336 & 381 & 322 & 299 \\ \text { RCP6 } & (93-519) & (104-578) & (118-657) & (99-559) & (93-515) \\ & 238 & 264 & 301 & 256 & 235 \\ \text { RCP4.5 } & (62-511) & (69-567) & (79-645) & (68-546) & (62-505) \\ & 279 & 309 & 351 & 297 & 276 \\ \text { RCP2.6 } & (77-478) & (84-530) & (93-602) & (81-507) & (77-473) \\ & 253 & 280 & 317 & 268 & 250 \\ & (83-473) & (93-525) & (105-596) & (90-503) & (83-468)\end{array}$

d) Numbers of people (millions) exposed to decreased river flood frequency

$\begin{array}{llllll}\text { RCP8.5 } & 168 & 183 & 201 & 184 & 170 \\ & (71-284) & (76-312) & (83-347) & (75-315) & (71-285) \\ \text { RCP6 } & 152 & 166 & 182 & 164 & 154 \\ & (72-257) & (77-279) & (82-309) & (74-264) & (73-257) \\ \text { RCP4.5 } & 140 & 153 & 168 & 154 & 142 \\ & (58-254) & (62-278) & (67-308) & (64-278) & (60-256) \\ \text { RCP2.6 } & 122 & 133 & 147 & 133 & 123 \\ & (39-216) & (42-242) & (45-273) & (42-248) & (39-216)\end{array}$

The table shows the ensemble mean across 19 climate models, together with the range across the climate models

than SSP2, whilst SSP2 has more people exposed to an increased frequency of river flooding. The differences in impact on exposure to increased water scarcity between SSPs would be greater if the indicator was based on withdrawals rather than just on exposed populations.

By 2050, there is little difference in temperature change between RCP2.6, RCP4.5 and RCP6.0 (Fig. 1), and this is reflected in the lack of a clear difference in impact, for a given 


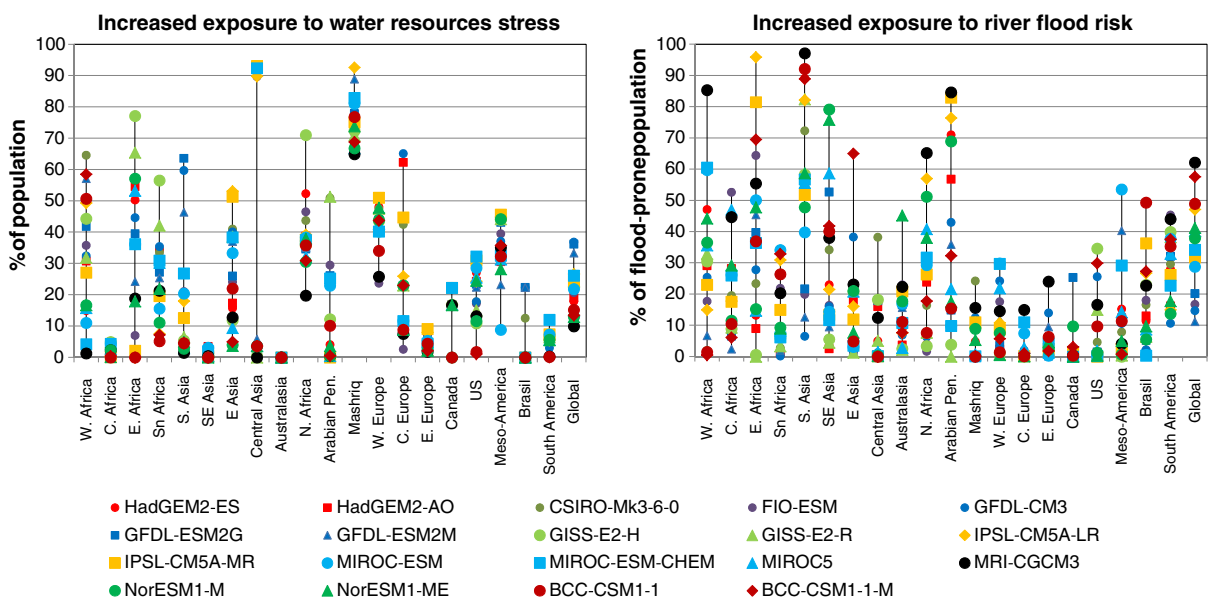

Fig. 3 Variation in regional impact on exposure to increased water resources stress and river flood risk: RCP8.5, SSP2, 2050

SSP, under these RCPs (Fig. 2 and Table 3). The differences between these three RCPs for a given model in 2050 reflect the effects of both year-to-year climatic variability on 30-year mean climate and the different aerosol scenarios: Chalmers et al. (2012) show that for the HadGEM2-ES model, for example, average temperature increase is greater under RCP2.6 than under RCP4.5 to at least 2040 because of the substantial reductions in aerosols, and that the spatial pattern of change in climate is different. Impacts under RCP8.5 in 2050 are typically larger than those under the other RCPs - but not always. Exposure to increased river flood frequency is less with HadGEM2-ES in 2050 under RCP8.5 than RCP2.6, and impacts with NorESM-M are larger under RCP4.5 than RCP8.5. This is likely to be due to the effects of multi-decadal variability.

Figure 2 and Table 3 show that for population exposed to changes in water scarcity, variation between SSPs is greater than variation across RCPs, but variation across different climate models is considerably greater. For populations exposed to changes in river flood frequency, the variations across RCP and SSP are similar, but again smaller than variations between climate models. Differences between the RCPs are greater in 2080 than in 2050 (Supplementary Table 2), but again RCP4.5 and RCP6.0 produce very similar impacts.

Figure 4 shows the relative contribution of uncertainty in climate model, RCP and SSP to the regional and global impact on absolute exposure to increased water resources scarcity and river flooding. It follows the methodology of Hawkins and Sutton (2009) (note that the effects of internal climatic variability are not included) and assumes that all climate models, RCPs and SSPs are equally plausible. This is, of course, unrealistic (and overstates the impact of uncertainty in future forcing in particular), so the plot should be regarded as indicative. Climate model uncertainty is largest, but SSP uncertainty becomes increasingly important through the 21 st century. SSP uncertainty has a greater effect on changes in exposure to water resources scarcity than on changes in exposure to flooding because the baseline 'no climate change' exposure varies more between SSPs (Table 2). There are variations in the relative contribution of the different sources of uncertainty between regions, particularly for water resources stress.

The difference between RCPs can be seen as an indication of the effect of climate policy on the impacts of climate change. RCP2.6, for example, is broadly consistent with an emissions policy that has a reasonable chance of achieving a $2{ }^{\circ} \mathrm{C}$ climate target (van Vuuren et al. 2011b). Such a policy would reduce exposure to increased water resources scarcity by - on average 420-530 million people, compared with RCP8.5 (Table 3a), or between $22 \%$ and $24 \%$. The 
Population exposedtoin creased water resources stress: 2050

Population exposed to increased flood frequency: 2050
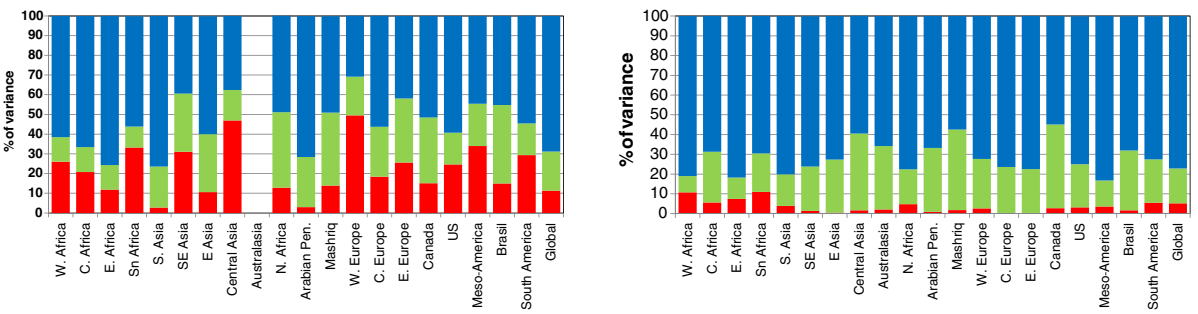

Population exposed to increased water resources stress: 2080

Population exposed to increased flood frequency: 2080
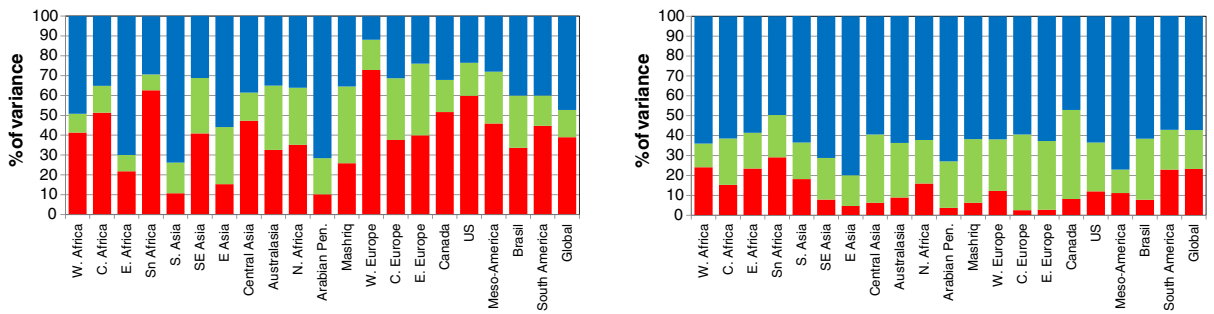

- Variance due to SSP $\square$ Variance due to RCP $\square$ Variance due to climate model

Fig. 4 The relative contribution of RCP, SSP and climate model uncertainty to projected regional impacts on exposure to water resources stress and river flood risk: 2050 and 2080

population exposed to increased river flood risk would reduce by $49-64$ million, or around $16 \%$. By 2080, RCP2.6 would reduce exposure to increased water scarcity by $600-1,200$ million people (27-32\%) and reduce exposure to increased flooding by 110-180 million (33\%). The proportions of impacts avoided are broadly consistent across SSPs, but the absolute amount of avoided impact (numbers of people) vary substantially between SSPs, particularly in 2080. The absolute avoided impact also varies between individual CMIP5 models.

\section{Comparisons with previous assessments}

There have been several previous assessments of the impacts of climate change on global water resources (see Section 2.5). These studies have used different indicators of impact, and several different climate and socio-economic scenarios. This section compares the results of the assessment presented here firstly with previous assessments using the same methodology, hydrological model and indicators but different climate scenarios, and secondly with the one study that has so far used RCPs, SSPs and CMIP5 climate models.

The approach, hydrological model and impact indicators used here have been used in previous assessments with SRES scenarios and CMIP3 climate models (Arnell and Gosling 2013b; Gosling and Arnell 2013) and with scenarios representing different emissions policies (Arnell et al. 2011, 2013). The closest comparison (in terms of population totals and change in global mean temperature) is between SRES A2 and RCP8.5 with SSP3. In 2050 under SRES A2, the ranges across climate models in the number of people exposed to increased water stress 
(Gosling and Arnell 2013) and a doubling of river flood frequency (Arnell and Gosling 2013b) are 705 to 4,747 million and 37 to 588 million people respectively. These compare with ranges across the CMIP5 climate models under RCP8.5 plus SSP3 of 1,006 to 4,201 million and 118 to 657 million respectively (Table 3 ). The ranges are not substantially different, and the ranges in impacts at the regional scale are also similar, suggesting that the CMIP5 climate model set does not substantially reduce the range in projected impacts of climate change (as noted for temperature and precipitation by Knutti and Sedlácek 2013).

Arnell et al. (2013) compared global-scale impacts under A1b and A1FI 'business-as-usual' emissions policies with impacts under a series of different emissions policy pathways. Their lowest emissions policy pathway produces similar changes in global mean temperature to RCP2.6, and avoids between $5 \%$ and $8 \%$ of the impacts in 2050 on exposure to increased water scarcity relative to A1b (varying with climate model pattern), and around $30-50 \%$ of impacts on exposure to increased river flood risk. These values are rather different to the ensemble mean CMIP5 percentage avoided (RCP2.6 compared with RCP8.5) is $22-24 \%$ and approximately $16 \%$ respectively - although there is large variability in the percentage impact avoided between the 19 CMIP5 models. There are several reasons for the differences. A different ensemble of climate models was used in the two assessments, with different spatial patterns of climate change. The global temperature difference between RCP8.5 and RCP2.6 varies between climate models (from 0.4 to $0.9^{\circ} \mathrm{C}$ in 2050), but in Arnell et al. (2013) the temperature difference was constant across all models $\left(0.48^{\circ} \mathrm{C}\right)$. The difference between RCP8.5 and RCP2.6 includes not only different radiative forcings, but also different aerosol emissions. Taken together, these differences have the result that climate policy as assessed in Arnell et al. (2013) has little effect on water resource scarcity in south and east Asia, but a large effect on exposure to increased flooding in east Asia, whilst in the assessment here the difference between RCP8.5 and RCP2.6 is large in most models in terms of water resources scarcity in south and east Asia, and generally small in terms of flood frequency in east Asia. Another comparison (Arnell et al. 2011) concluded that exposure to increased water resources scarcity was $8-17 \%$ less with a $2{ }^{\circ} \mathrm{C}$ pathway than under a $4{ }^{\circ} \mathrm{C}$ pathway (Arnell et al. 2011) - slightly less than found here - and again the differences can largely be attributed to the use of different climate models.

Hanasaki et al. (2013) assessed the impact of climate change on exposure to water resources scarcity under RCPs and SSPs, but used only three CMIP5 climate models and did not estimate impacts under all combinations of RCP and SSP. They also used different indicators of water resources stress (based on the ratio of withdrawals to availability, and on the cumulative ratio of withdrawals to consumptive demands), and calculated indicators at the grid rather than the basin scale, so their results are not directly comparable with those presented here. Their estimates of population exposed to changes in water resources stress are considerably higher than those presented here. For example, for SSP2 and RCP8.5 in 2050, they estimated that between 7.1 and 7.9 billion people living in grid cells with withdrawals greater than $40 \%$ of runoff would be exposed to increased water resources stress, which compares with the estimate here (Table 3 ) of 0.9 to 3.4 billion people exposed to increased stress. The assessment here also produces a wider range of impacts for a given RCP and SSP because it uses 19 rather than just 3 climate models.

\section{Conclusions}

This paper has presented a preliminary assessment of the relative effects of rate of climate change (four Representative Concentration Pathways), assumed future population (five Shared Socio-economic Pathways), and the spatial and seasonal pattern of climate change (19 CMIP5 climate models) on regional and global exposure to water resources stress and 
river flooding. There are a number of caveats with the assessment. Only one impact model is used to translate climate changes into changes in river flows, climate scenarios represent just change in mean climate, and the SSP characterisations are preliminary. Most significantly, only simple indicators of changes in exposure to water resources scarcity and river flood frequency are used. These indicators consider only population, and do not incorporate other differences between socio-economic scenarios such as differences in water withdrawals or rate of urbanisation. Including such additional dimensions would increase the differences between the SSPs. Future asssessments should include more sophisticated measures of exposure and impact, and incorporate the effects of impact model uncertainty.

The key conclusion is that uncertainty in the projected future impacts of climate change on exposure to water stress and river flooding is dominated by uncertainty in the projected spatial and seasonal pattern of change in climate (especially precipitation), as represented by the 19 climate models. The range in impacts across models is similar to the range from previous generations of climate models. There is little clear difference between RCP2.6, RCP4.5 and RCP6.0 at 2050, and between RCP4.5 and RCP6.0 at 2080. Impacts under RCP8.5 are greater than under the other RCPs in 2050 and 2080. For a given RCP, there is a difference in the absolute numbers of people exposed to increased water resources stress or increased river flood frequency between the five SSPs, with most climate models, even with the simple impact indicators used here.

The analysis here has focused on the numbers of people exposed to increased water resources stress or river flood frequency, but a particular strength of the new SSPs is their characterisation not only in quantitative terms, but also in terms of challenges to mitigation and adaptation. Under each RCP and climate model, more people are exposed to increased water resources stress under SSP4 than SSP1, but under SSP4 the challenges in adapting to these pressures are, by definition, much greater; the difference in 'actual' impact (represented for example in terms of cost of adaptation or the residual impacts after adaptation) between the two SSPs is likely to be considerably greater than the apparent difference in numbers of people exposed to impact. Similarly, SSP1 and SSP4 produce very similar numbers of people exposed to increased river flood frequency, but the consequences of this in practice will likely be much greater under SSP4-with its greater adaptation challenges - than under SSP1. The assessment of such differences requires the development and implementation of much more sophisticated models which simulate not only the impacts of climate change but also the uptake and effectiveness of adaptation measures, and which characterise impacts in terms directly relevant to the economy and society.

Acknowledgments The research presented in this paper was supported by the AVOID programme (UK Department of Energy and Climate Change (DECC) and Department for Environment, Food and Rural Affairs (DEFRA) under contract GA0215, and builds on the QUEST-GSI project funded by NERC (grant number NE/E001882/1). The CMIP5 data sets were extracted from the Program for Climate Model Diagnosis and Intercomparison (pcmdi3.llnl.gov/esgcet). We acknowledge the World Climate Research Programme's Working Group on Coupled Modelling, which is responsible for CMIP, and we thank the climate modelling groups for producing and making available their model output. The SSP population projections were downloaded from https://secure.iiasa.ac.at/web-apps/ene/SspDb (SSP version 0.93). Summary statistics for the simulated runoff data are available at badc.nerc.ac.uk/browse/badc/quest/qgsi.

Open Access This article is distributed under the terms of the Creative Commons Attribution License which permits any use, distribution, and reproduction in any medium, provided the original author(s) and the source are credited.

\section{References}

Alcamo J, Florke M, Marker M (2007) Future long-term changes in global water resources driven by socioeconomic and climatic changes. Hydrol Sci J 52:247-275 
Allan RP, Soden BJ (2008) Atmospheric warming and the amplification of precipitation extremes. Science 321:1481-1484

Allan RP, Liu C, Zahn M, Lavers DA, Koukouvagias E, Bodas-Salcedo A (2013) Physically consistent responses of the global atmospheric hydrological cycle in models and observations. Surv Geophys. doi:10.1007/ s10712-012-9213-z

Arnell NW (2004) Climate change and global water resources: SRES emissions and socio-economic scenarios. Glob Environ Chang Hum Policy Dimens 14:31-52

Arnell NW, Gosling SN (2013a) The impacts of climate change on river flow regimes at the global scale. J Hydrol 486:351-364

Arnell NW, Gosling SN (2013b) The impacts of climate change on river flood risk at the global scale. Under review

Arnell NW, van Vuuren DP, Isaac M (2011) The implications of climate policy for the impacts of climate change on global water resources. Glob Environ Chang Hum Policy Dimens 21:592-603

Arnell NW, Lowe JA, Brown S, Gosling SN, Gottschalk P, Hinkel J, Lloyd-Hughes B, Nicholls RJ, Osborn TJ, Osborne TM, Rose GA, Smith P, Warren RF (2013) A global assessment of the effects of climate policy on the impacts of climate change. Nat Clim Chang 3:512-519

Center for International Earth Science Information Network (CIESIN) CU, (IFPRI); IFPRI, Bank; TW, (CIAT). CIdAT (2004) Global Rural-urban Mapping Project (GRUMP), Alpha Version: Population Grids. Socioeconomic Data and Applications Center (SEDAC), Columbia University. Available at http://sedac.ciesin.columbia.edu/gpw. (1 April 2011). Palisades, NY

Chalmers N, Highwood EJ, Hawkins E, Sutton R, Wilcox LJ (2012) Aerosol contribution to the rapid warming of near-term climate under RCP 2.6. Geophys Res Lett 39. doi:10.1029/2012g1052848

Diffenbaugh NS, Giorgi F (2012) Climate change hotspots in the CMIP5 global climate model ensemble. Clim Chang 114:813-822

Gerten D, Heinke J, Hoff H, Biemans H, Fader M, Waha K (2011) Global water availability and requirements for future food production. J Hydrometeorol 12:885-899

Gosling SN, Arnell NW (2011) Simulating current global river runoff with a global hydrological model: model revisions, validation, and sensitivity analysis. Hydrol Process 25:1129-1145

Gosling SN, Arnell NW (2013) A global assessment of the impact of climate change on water scarcity. Clim Chang. doi:10.1007/s10584-013-0853-x

Haddeland I, Clark DB, Franssen W, Ludwig F, Voss F, Arnell NW, Bertrand N, Best M, Folwell S, Gerten D, Gomes S, Gosling SN, Hagemann S, Hanasaki N, Harding R, Heinke J, Kabat P, Koirala S, Oki T, Polcher J, Stacke T, Viterbo P, Weedon GP, Yeh P (2011) Multimodel estimate of the global terrestrial water balance: setup and first results. J Hydrometeorol 12:869-884

Hagemann S, Chen C, Clark DB, Folwell S, Gosling SN, Haddeland I, Hanasaki N, Heinke J, Ludwig F, Voss F, Wiltshire AJ (2013) Climate change impact on available water resources obtained using multiple global climate and hydrology models. Earth Syst Dyn 4:129-144

Hanasaki N, Kanae S, Oki T, Masuda K, Motoya K, Shirakawa N, Shen Y, Tanaka K (2008) An integrated model for the assessment of global water resources part 2: applications and assessments. Hydrol Earth Syst Sci 12:1027-1037

Hanasaki N, Fujimori S, Yamamoto T, Yoshikawa S, Masaki Y, Hijioka Y, Kainuma M, Kanamori Y, Masui T, Takahashi K, Kanae S (2013) A global water scarcity assessment under shared socio-economic pathways - part 2: water availability and scarcity. Hydrol Earth Syst Sci 17:2393-2413

Harris I, Jones PD, Osborn TJ, Lister DH (2013) Updated high-resolution grids of monthly climatic observations - the CRU TS3.10 data set. Int J Climatol. doi:10.1002/joc.3711

Hawkins E, Sutton R (2009) The potential to narrow uncertainties in regional climate predictions. Bull Am Meteorol Soc 90:1095-1107

Hayashi A, Akimoto K, Sano F, Mori S, Tomoda T (2010) Evaluation of global warming impacts for different levels of stabilization as a step toward determination of the long-term stabilization target. Clim Chang $98: 87-112$

IPCC (2000) Special report on emissions scenarios. Intergovernmental panel on climate change. Cambridge University Press, Cambridge

Knutti R, Sedláceek J (2013) Robustness and uncertainties in the new CMIP5 climate model projections. Nat Clim Chang 3:369-373. doi:10.1038/nclimate1716

Knutti R, Masson R, Gettelman A (2013) Climate model genealogy: generation CMIP5 and how we got there. Geophys Res Lett 40:1194-1199

Monerie PA, Fontaine B, Roucou P (2012) Expected future changes in the African monsoon between 2030 and 2070 using some CMIP3 and CMIP5 models under a medium-low RCP scenario. J Geophys Resh Atmos 117. doi:10.1029/2012jd017510

Moss RH, Edmonds JA, Hibbard KA, Manning MR, Rose SK, van Vuuren DP, Carter TR, Emori S, Kainuma M, Kram T, Meehl GA, Mitchell JFB, Nakicenovic N, Riahi K, Smith SJ, Stouffer RJ, Thomson AM, 
Weyant JP, Wilbanks TJ (2010) The next generation of scenarios for climate change research and assessment. Nature 463:747-756

Oki T, Kanae S (2006) Global hydrological cycles and world water resources. Science 313:1068-1072

O’Neill BC, Carter TR, Ebi KL, Edmonds J, Hallegatte S, Kemp-Benedict E, Kriegler E, Mearns LO, Moss RH, Riahi K, van Ruijven B, van Vuuren D (2012) Meeting report of the workshop on the nature and use of new socio-economic pathways for climate change research, Boulder, CO, November 2-4, 2011. Available at: http://www.isp.ucar.edu/socio-economic-pathways

Rockstrom J, Falkenmark M, Karlberg L, Hoff H, Rost S, Gerten D (2009) Future water availability for global food production: the potential of green water for increasing resilience to global change. Water Resour Res 45:W00A12. doi:10.1029/2007WR006767

Scheff J, Frierson DMW (2012) Robust future precipitation declines in CMIP5 largely reflect the poleward expansion of model subtropical dry zones. Geophys Res Lett 39, L18704. doi:10.1029/2012gl052910

Shen YJ, Oki T, Utsumi N, Kanae S, Hanasaki N (2008) Projection of future world water resources under SRES scenarios: water withdrawal. Hydrol Sci J 53:11-33

Taylor KE, Stouffer RJ, Meehl GA (2012) An overview of CMIP5 and the experimental design. Bull Am Meteorol Soc 93:485-498

van Vuuren DP, Den Elzen MGJ, Lucas PL, Eickhout B, Strengers BJ, van Ruijven B, Wonink S, van Houdt R (2007) Stabilizing greenhouse gas concentrations at low levels: an assessment of reduction strategies and costs. Clim Chang 81:119-159

van Vuuren DP, Edmonds J, Kainuma M, Riahi K, Thomson A, Hibbard K, Hurtt GC, Kram T, Krey V, Lamarque JF, Masui T, Meinshausen M, Nakicenovic N, Smith SJ, Rose SK (2011a) The representative concentration pathways: an overview. Clim Chang 109:5-31

van Vuuren DP, Stehfest E, den Elzen MGJ, Kram T, van Vliet J, Deetman S, Isaac M, Goldewijk KK, Hof A, Beltran AM, Oostenrijk R, van Ruijven B (2011b) RCP2.6: exploring the possibility to keep global mean temperature increase below 2 degrees C. Clim Chang 109:95-116

van Vuuren DP, Riahi K, Moss R, Edmonds J, Thomson A, Nakicenovic N, Kram T, Berkhout F, Swart R, Janetos A, Rose SK, Arnell N (2012) A proposal for a new scenario framework to support research and assessment in different climate research communities. Glob Environ Chang Hum Policy Dimens 22:21-35

Wada Y, van Beek LPH, Viviroli D, Durr HH, Weingartner R, Bierkens MFP (2011) Global monthly water stress: 2. Water demand and severity of water stress. Water Resour Res 47. doi:10.1029/2010wr009792 